\title{
Production and Properties of a New Wood Laminated Veneer/High-Density Polyethylene Composite Board
}

\author{
Emanuela Camargo de Barros Lustosa ${ }^{a}$, Cláudio Henrique Soares Del Menezzi ${ }^{a *}$,
}

Rafael Rodolfo de Melo ${ }^{b}$

\author{
${ }^{a}$ Departamento de Engenharia Florestal, Faculdade de Tecnologia, Universidade de Brasília - UnB, \\ CP 04357, CEP 70904-970, Brasília, DF, Brazil \\ ${ }^{b}$ Instituto de Ciências Agrárias e Ambientais - ICAA, Universidade Federal de Mato Grosso - UFMT, \\ CEP 78557-267, Sinop, MT, Brazil
}

Received: May 21, 2015; Accepted: July 17, 2015

\begin{abstract}
The paper aimed at evaluating the feasibility and the properties of a new product which combines wood veneer and high-density polyethylene (HDPE) from post-consuming plastic bags. Three HDPE amounts were evaluated: $150 \mathrm{~g} / \mathrm{m}^{2}, 250 \mathrm{~g} / \mathrm{m}^{2}$ e $350 \mathrm{~g} / \mathrm{m}^{2}$. The boards were manufactured using a single-opening hot-press under such conditions: $140^{\circ} \mathrm{C}$, for 20 minutes and pressure of $1 \mathrm{~N} / \mathrm{mm}^{2}$. It was found that the production of this kind of composite board is technically possible and relatively simple and they did not present any veneer delamination. The properties of the composite boards were quite similar or even higher to those found in LVL made using thermosetting resin. The higher the HDPE amount the higher the density of the composite board, which imparted significantly in mechanical properties. However, when the composite boards were evaluated under same density the effect of the HDPE amount affected only Janka hardness.
\end{abstract}

Keywords: laminated veneer lumber, post-consuming plastic bag, recycling

\section{Introduction}

Six and half million tons of thermoplastic resins were consumed in 2011, and approximately $21.7 \%$ of plastics were recycled in Brazil this period, representing approximately 953,000 tons per year ${ }^{1}$. In a framework on the main materials participation in total MSW (Municipal Solid Waste) collected in Brazil in 2012, the plastic residues quantified $7,635,851 \mathrm{t} /$ year. The plastics recycling in Brazil portrays the universe of the plastics mechanical recycling industry, which converts the disposed post-consumer plastics materials in granules which may be utilized in the production of new plastic artifacts ${ }^{2}$. The final destination of solid residues, mainly plastic, represent a major concern of the current society: the growing technological development generates residues in large quantity, damaging the environment and the population, in this scenario recycling has been a promising route to divert these dumpsites or landfills residues and reduce production costs by replacing raw material.

The polyethylene was the most used plastic in flexible packaging in 2013, wherein the plastic had less participation in the flexible plastic packaging production in Brazil in 2013, thus being HDPE (high-density polyethylene) highlighted. It appears with 262,000 tons equivalent to $26 \%$ of total demand, the main customer is the personal care industry and household cleaning, with $27 \%$ of participation, followed by disposable that are basically represented by plastic bags from supermarket $(19 \%)$ and farming $(8 \%)$; foods have

*e-mail: cmenezzi@unb.br participation of only $4 \%{ }^{3}$. Plastic residues constitute one of the major current problems, among these; we have plastic bags from supermarkets. Due to their frequent use, mainly by supermarkets consumer, it is necessary a study on the reuse of this material for other purposes, seeking to minimize the impacts caused by improper disposal of these residues.

The manufacture of wood-plastic composites has become a good option for the recycling of plastic residues as well as wood residues. These products may be obtained from a continuous or discontinuous matrix of thermoplastic resin and wood particles, thus, the obtained products combine the best qualities of each constituent ${ }^{4}$. However, the woods that are often utilized in this process are in particles, crumbs or flour form, thus it is necessary to assess the possibility of manufacturing wood-plastic composites with wood in other forms, such as in veneer format.

Laminated veneer lumber (LVL) is a structural board made from thin lumber veneers which are subsequently arranged and bonded in the same grain direction. Due to their high mechanical strength and great dimensional stability LVL boards have been used for structural purpose in building and housing. However, the thermosetting adhesives used to bond the veneer such as urea-formaldehyde and phenol-formaldehyde represent the largest cost in the production of reconstituted wood composite boards ${ }^{5}$. The high price of these adhesives is owing to the constant variation of petroleum costs and the production expansion of reconstituted wood products, pushing studies that seek to find more economical alternative 
adhesives, less injurious to the environment and with high resistance ${ }^{6}$.

A reduction of the LVL manufacturing cost and assuage the issue of plastic residue improper disposal may be provided with the possibility of using plastic residue to provide bonding between wood veneers. In this case the plastic residue would come from supermarket plastic bags made from HDPE, which is easy to be obtained and presents sheet format required to promote a more homogeneous distribution between the boards' veneers that will be produced.

This study aiming to assess the viability of producing laminated veneer lumber (LVL) using high-density polyethylene (HDPE) from supermarket plastic bags as a binding agent, in order to encourage recycling of plastic residues providing its reuse for the wood-plastic laminates composites manufacture as an alternative to solid wood.

\section{Material and Methods}

\subsection{Production of the composite boards}

Wood veneers from amescla wood (Trattinnickia burseraefolia) were used to manufacture the composite boards ${ }^{7}$. The veneers' size was $50 \mathrm{~cm}$ x $50 \mathrm{~cm}$, and 3 to $4 \mathrm{~mm}$ thickness, and was subsequently sectioned into three $16.5 \mathrm{~cm}$ x $50 \mathrm{~cm}$ veneers. The equilibrium moisture content of the wood veneers was about 11-12\%. After climatization, the veneers had the three dimensions measured (v) and were weighted $(\mathrm{m})$ to determine the density $(\rho=\mathrm{m} / \mathrm{v})$. The material was randomized according to density for veneers separation to be used in each treatment, and after treatment separation, they were randomized again by board, wherefore each board in each treatment presented similar density taking into account only the wood part of the composite.

Four veneers interspersed with high-density polyethylene (HDPE) supermarket plastic bags were utilized for production of each board. The LVL-HDPE composite boards measuring $16.5 \mathrm{~cm}$ x $50 \mathrm{~cm} \times 1.2-1.6 \mathrm{~cm}$ (width x length $\times$ thickness) were flat compressed using a hydraulic press (INDUMEC, $1000 \mathrm{kN}$ ) with automatic control of temperature and pressure. Each set was taken to press until the melting point of the $\operatorname{HDPE}\left(+/-140^{\circ} \mathrm{C}\right)$ for 20 minutes with adequate pressure to the set $\left(\cong 1 \mathrm{~N} / \mathrm{mm}^{2}\right)$. Three treatments were studied varying the amount of HDPE to be used: $150 \mathrm{~g} / \mathrm{m}^{2}, 250 \mathrm{~g} / \mathrm{m}^{2}$ and $350 \mathrm{~g} / \mathrm{m}^{2}$. Four boards were manufactured for each treatment, totaling 12 LVL-HDPE composite boards.

\subsection{Physical and mechanical testing}

Eight samples for each treatment were cut longitudinally after boards' production, totalizing 24 samples per test. These samples were put in air-conditioning room $\left(20^{\circ} \mathrm{C} / 65 \%\right)$ up to achieve constant mass. The performed tests were: three-point static bending to obtain the modulus of rupture $\left(f_{\mathrm{m}}\right)$ and modulus of elasticity $\left(E_{M}\right)$, screw withdrawal resistance, Janka hardness $\left(f_{\mathrm{H}}\right)$, thickness swelling and water absorption (TS; WA $)^{8}$; parallel compression strength $\left(f_{\mathrm{c}, 0}\right)^{9}$; and parallel shear strength $\left(f_{\mathrm{v}, 0}\right)^{10}$.

\subsection{Statistical analysis}

The results obtained for the three treatments initially were evaluated by analysis of variance (ANOVA) followed by Tukey test at $\alpha=0.05$ to verify whether difference between means was statistically significant. Pearson correlation analysis (r) between density and material properties was also performed in order to explain the properties variation. Further analysis of the covariance (ANCOVA) was run, with density entering as a covariant factor. In this analysis, the material properties were estimated in the same density and compared using Bonferroni test at at $\alpha=0.05$.

\section{Results and Discussion}

\subsection{Manufacturing process}

The production of the LVL-HDPE composite board was considered very simple and showed be technically possible at least at lab conditions. Differently from other wood-plastic composites, whose moisture content of the wood flour must be quite low $(<2 \%)$, the veneer does not need be dried up to such very low moisture content. It happens because of its shape and wood anatomical organization. This way, when the composite is hot-pressed the water vapor coming from veneer drying can be easily eliminated through the wood vessels and fibers which are positioned longitudinally. As the plastic material is not involving nor blocking the veneer wood structures the vapor can go away easily. In consequence, no bubbles nor veneer delamination were observed.

Figure 1 shows the appearance of the HDPE bonding line between veneers as seen at longitudinal (A) and transversal (B) directions. It can be seen that bonding line becomes thicker as the amount of HDPE ranges from $150 \mathrm{~g} / \mathrm{m}^{2}$ to $350 \mathrm{~g} / \mathrm{m}^{2}$. Very thin bonding lines were obtained when $150 \mathrm{~g} / \mathrm{m}^{2}$ of HDPE was employed and they are almost invisible at naked eyes. It can be also observed that thicker bonding lines $\left(250\right.$ and $\left.350 \mathrm{~g} / \mathrm{m}^{2}\right)$ followed the profile of the wood veneer, filling the voids and molding to its surface.

Before deciding about the pressing conditions, an exploratory evaluation was done. Three temperatures $\left(100^{\circ} \mathrm{C}\right.$, $120^{\circ} \mathrm{C}$ and $140^{\circ} \mathrm{C}$ ) for 10 and 15 minutes at $1 \mathrm{~N} / \mathrm{mm}^{2}$ were tested. It was found that lower temperatures did not promote an adequate melting of the HDPE. On the other hand, when the composite was pressed at $140^{\circ} \mathrm{C}$ for 15 minutes the result was better. In this context, it can be inferred that pressing conditions chosen $\left(140^{\circ} \mathrm{C} ; 20\right.$ minutes; $\left.1 \mathrm{~N} / \mathrm{mm}^{2}\right)$ were suitable for manufacturing this kind of composite board.

Although the pressing temperature was higher than that required for melting the HDPE, it allowed faster heating of the composite board, reducing the time for production. Additionally, the hot pressing could not also be so long in order to prevent thermal degradation of the wood veneer. This way, the time used was enough for heating the inner areas of the composite boards allowing the melting of the HDPE and the drying of the wood veneer at same time. The pressure also played an important role because it is responsible for providing close contact between both material and helping the flow of the HDPE into voids and irregularities of the wood veneer.

\subsection{Density and mechanical properties}

The increased amount of plastic resulted in increase of the density of the composite boards, which ranged from 643.43 to $664.21 \mathrm{~kg} / \mathrm{m}^{3}$ (Table 1) and showed a significant difference. The density is directly related to the mechanical strength properties, dimensional stability and water absorption, 


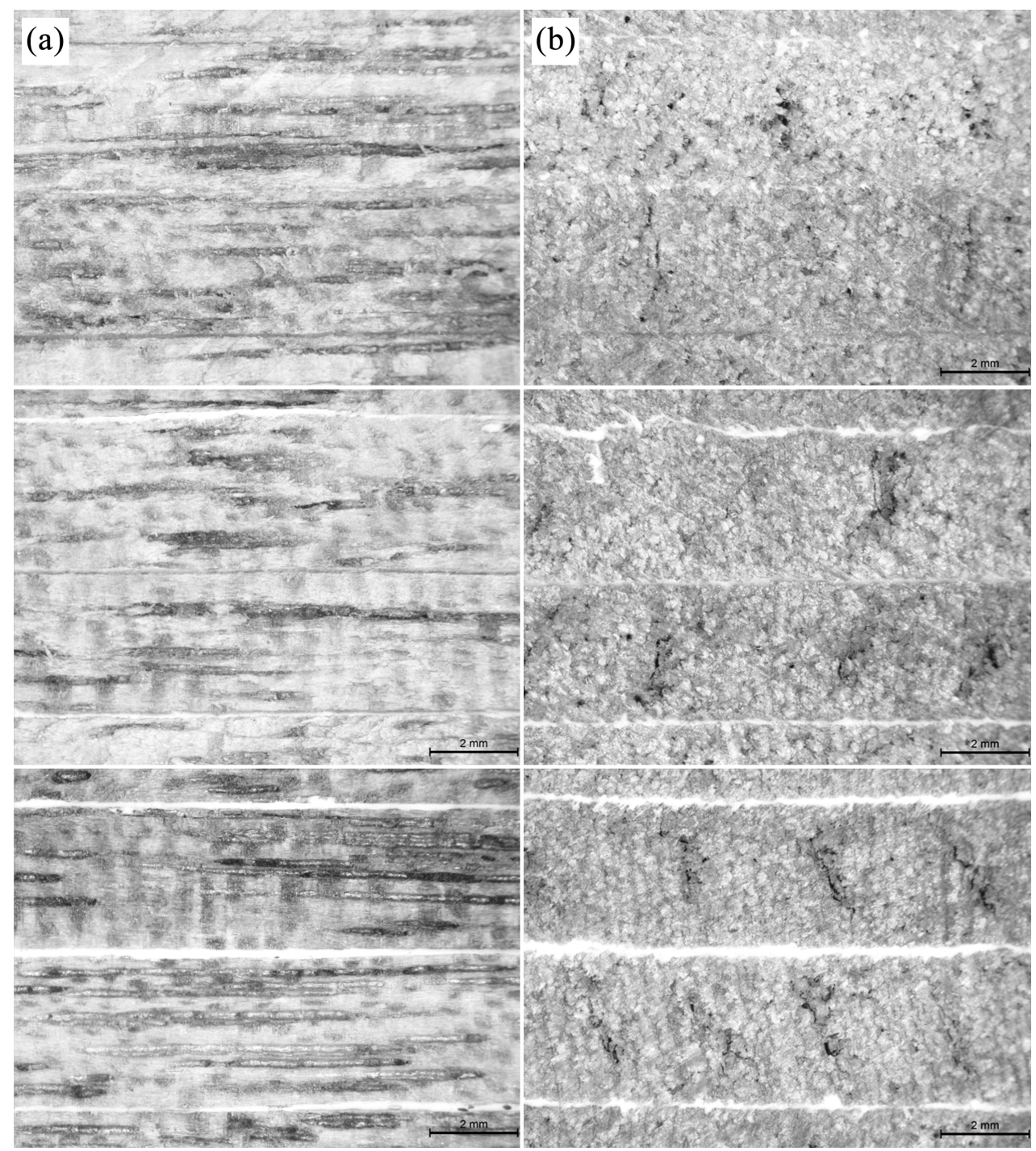

Figure 1. Macroscopic images of LVL composite boards cut in longitudinal (a) and transversal (b) directions manufactured with $150 \mathrm{~g} / \mathrm{m}^{2}$ (top), $250 \mathrm{~g} / \mathrm{m}^{2}$ (middle) and $350 \mathrm{~g} / \mathrm{m}^{2}$ (bottom) of HDPE.

Table 1. Density and mechanical properties of the LVL composite board according to the amount of HDPE.

\begin{tabular}{cccc}
\hline \multirow{2}{*}{ Property } & \multicolumn{3}{c}{ HDPE amount $\left(\mathbf{g} / \mathbf{m}^{2}\right)$} \\
\cline { 2 - 4 } & $\mathbf{1 5 0}$ & $\mathbf{2 5 0}$ & $\mathbf{3 5 0}$ \\
\hline$\rho\left(\mathrm{kg} / \mathrm{m}^{3}\right)$ & $643.4 \mathrm{a}$ & $664.1 \mathrm{~b}$ & $664.2 \mathrm{~b}$ \\
& $(10.5)$ & $(4.32)$ & $(10.67)$ \\
$\mathrm{f}_{\mathrm{M}}\left(\mathrm{N} / \mathrm{mm}^{2}\right)$ & $88.5 \mathrm{a}$ & $98.8 \mathrm{~b}$ & $93.7 \mathrm{a}$ \\
& $(8.71)$ & $(9.25)$ & $(13.1)$ \\
$\mathrm{E}_{\mathrm{M}}\left(\mathrm{N} / \mathrm{mm}^{2}\right)$ & $9641 \mathrm{a}$ & $10520 \mathrm{~b}$ & $11158 \mathrm{c}$ \\
& $(937)$ & $(599)$ & $(757)$ \\
$\mathrm{f}_{\mathrm{v}, 0}\left(\mathrm{~N} / \mathrm{mm}^{2}\right)$ & $2.05 \mathrm{a}$ & $2.51 \mathrm{a}$ & $2.41 \mathrm{a}$ \\
& $(0.33)$ & $(0.11)$ & $(0.53)$ \\
$\mathrm{f}_{\mathrm{H}}(\mathrm{N})$ & $3158 \mathrm{a}$ & $4380 \mathrm{ab}$ & $4512 \mathrm{~b}$ \\
& $(807)$ & $(170)$ & $(203)$ \\
$\mathrm{f}_{\mathrm{c}, 0}\left(\mathrm{~N} / \mathrm{mm}^{2}\right)$ & $51.8 \mathrm{a}$ & $53.2 \mathrm{a}$ & $54 \mathrm{a}$ \\
& $(5.12)$ & $(4.48)$ & $(2.07)$ \\
$\mathrm{Screw}(\mathrm{N})$ & $1524 \mathrm{a}$ & $1737 \mathrm{a}$ & $1789 \mathrm{a}$ \\
& $(407)$ & $(126)$ & $(198)$ \\
\hline
\end{tabular}

At same line means followed by different letter denotes that they are statistically different according to the Tukey test at $\alpha=0.05$; Values between parenthesis are standard deviation. as most of the physical and technological properties depends on the density, in practice it ends up as a parameter for a product classification ${ }^{11}$.

Thus, we are predicting that the higher the wood-plastic composite laminated density, higher will be the physical and mechanical properties that depend on density. This way, to evaluate only the effect of the amount on the composite mechanical and physical properties is necessary to remove the density effect, since this influence the composite properties.

The modulus of rupture $\left(f_{\mathrm{m}}\right)$ showed mean values from 88.49 to $98.84 \mathrm{~N} / \mathrm{mm}^{2}$, with significant difference at 5\% significance level by ANOVA, as shown in Table 1 . The $250 \mathrm{~g} / \mathrm{m}^{2}$ treatment showed higher mean value of modulus of rupture, while the $150 \mathrm{~g} / \mathrm{m}^{2}$ treatment had the lowest mean value of modulus of rupture. The modulus of elasticity $\left(E_{M}\right)$ showed mean values from 9641.33 to $11157.67 \mathrm{~N} / \mathrm{mm}^{2}$, presenting significant difference. The $350 \mathrm{~g} / \mathrm{m}^{2}$ treatment showed higher mean value to modulus of elasticity, although the $150 \mathrm{~g} / \mathrm{m}^{2}$ treatment showed the lowest mean value for modulus of elasticity. Usually, the stiffness of wood plastic composites (WPC) is improved when they are reinforced 
with crescent amount of wood flour. However, the results presented here show an opposite behavior, since the stiffness of the composite board was improved when higher amount of HDPE $\left(350 \mathrm{~g} / \mathrm{m}^{2}\right)$ was used. It happened because the density was higher in this treatment which affected the stiffness of the composite board.

Souza et al. ${ }^{12}$ found the following values: modulus of rupture $\left(f_{\mathrm{m}}\right) 85$ and $94 \mathrm{~N} / \mathrm{mm}^{2}$; modulus of elasticity $\left(E_{M}\right)$ 16199 and $17087 \mathrm{~N} / \mathrm{mm}^{2}$, utilizing adhesive based on phenol-formaldehyde CR-7010 for LVLs boards, made with the Pinus oocarpa and P. kesiya. In the Amorim study ${ }^{7}$ on the LVLs boards properties produced from the veneers grouping of Amazon timber species (amescla, copaiba, curupixá, paricá and visgueiro), utilizing PVA "crosslinking" MultiBond ${ }^{\circledR}$ $\mathrm{X}-080$ adhesive, the modulus of rupture values ranged from 36.1 to $92.1 \mathrm{~N} / \mathrm{mm}^{2}$ and modulus of elasticity ranged from 4904 to $12380 \mathrm{~N} / \mathrm{mm}^{2}$. In a study on the physical and mechanical properties of Eucalyptus grandis LVL boards, using resin based on phenol-formaldehyde CR-7010, it was found a mean modulus of rupture about $88.76 \mathrm{~N} / \mathrm{mm}^{2}$ and mean modulus of elasticity of $13114 \mathrm{~N} / \mathrm{mm}^{2[13]}$. In a study on the LVL produced with Eucalyptus grandis Hill ex Maiden and E. dunnii Maiden woods, using phenol formaldehyde resin, it was found mean values of modulus of rupture ranging from 925 to $1377 \mathrm{kgf} / \mathrm{cm}^{2}$ (from 90.77 to $135.13 \mathrm{~N} / \mathrm{mm}^{2}$ ), while for modulus of elasticity the mean values varied from 127647 to $183103 \mathrm{kgf} / \mathrm{cm}^{2}$ (from 12526.69 to $17968.89 \mathrm{~N} / \mathrm{mm}^{2}$ ) ${ }^{14}$.

The mean values of resistance observed for screw withdrawal ranged from 1524.25 to $1788.88 \mathrm{~N}$, with no statistic difference at 5\% significance level by variance analysis. The $150 \mathrm{~g} / \mathrm{m}^{2}$ treatment presented lower mean value of resistance when the screw withdrawal, whereas the $350 \mathrm{~g} / \mathrm{m}^{2}$ treatment showed the higher mean value observed (Table 1). The mean values observed for the Janka hardness ranged from 3434.50 to $4552.51 \mathrm{~N}$, presenting significant difference. The $150 \mathrm{~g} / \mathrm{m}^{2}$ treatment showed lower mean value of hardness, whereas the $350 \mathrm{~g} / \mathrm{m}^{2}$ treatment showed higher mean value of hardness.

The mean values observed for parallel compression strength $\left(f_{\mathrm{c}, 0}\right)$ ranged from $51.76 \mathrm{~N} / \mathrm{mm}^{2}$ to $54.03 \mathrm{~N} / \mathrm{mm}^{2}$, with no statistic difference at 5\% significance level by ANOVA. The mean values observed for parallel shear strength $\left(f_{\mathrm{v}, 0}\right)$ ranged from $2.05 \mathrm{~N} / \mathrm{mm}^{2}$ to $2.50 \mathrm{~N} / \mathrm{mm}^{2}$, with no statistical difference. Parallel shear strength is a very important property, since it measures the degree of bonding between wood veneer and HDPE. In a composite board the role of the polymeric matrix is transfer mechanical stresses between composites elements. With the visual analysis of shear ruptures (Figure 2), it was observed that the $150 \mathrm{~g} / \mathrm{m}^{2}$ treatment, in general, showed the highest rupture percentage in the wood when compared to the other treatments. In this case it means that bonding provided by the HDPE presented strength higher than those found for the wood. In the $250 \mathrm{~g} / \mathrm{m}^{2}$ treatment some test samples showed the rupture almost complete in the HDPE bonding line, but in other test samples the rupture occurred in the wood, the same occurred to the $350 \mathrm{~g} / \mathrm{m}^{2}$ treatment. It was found that most of these bonding line ruptures occurred in the area when the plastic had been printed. One of the possible explanations could be the presence of the pigments in the ink, which present certain level of heat resistance and thus preventing the complete melting of this specific printed area.

Souza et al. ${ }^{12}$ found resistance to parallel compression of $55 \mathrm{~N} / \mathrm{mm}^{2}$ and $57 \mathrm{~N} / \mathrm{mm}^{2}$ fibers for LVLs boards of P. oocarpa and P. kesiya. Amorim ${ }^{7}$ found resistance to parallel compression ranging from 19.8 to $51.7 \mathrm{~N} / \mathrm{mm}^{2}$ for LVLs boards. Palma \& Ballarin ${ }^{13}$, in a study performed with LVLs boards made with a mix of tropical pinus veneers (P. caribaea var. caribaea, P. caribaea var. bahamensis, $P$. caribaea var. hondurensis and $P$. oocarpa) utilizing the phenol formaldehyde CR-7010 resin adhesive, they found resistance values for parallel compression ranging from 38.35 to $46.84 \mathrm{~N} / \mathrm{mm}^{2}$, with an average of $42.22 \mathrm{~N} / \mathrm{mm}^{2}$. In this study LVL make $E$. grandis, found resistance values for parallel compression ranging from 47.69 to $66.65 \mathrm{~N} / \mathrm{mm}^{2}$, with an average equal to $58.05 \mathrm{~N} / \mathrm{mm}^{2}$.

Gabriel $^{15}$, in a study on the physical and mechanical performance of tropical pinus LVL boards, using adhesive based on phenol formaldehyde, with veneers previously classified into quality classes according to the modulus
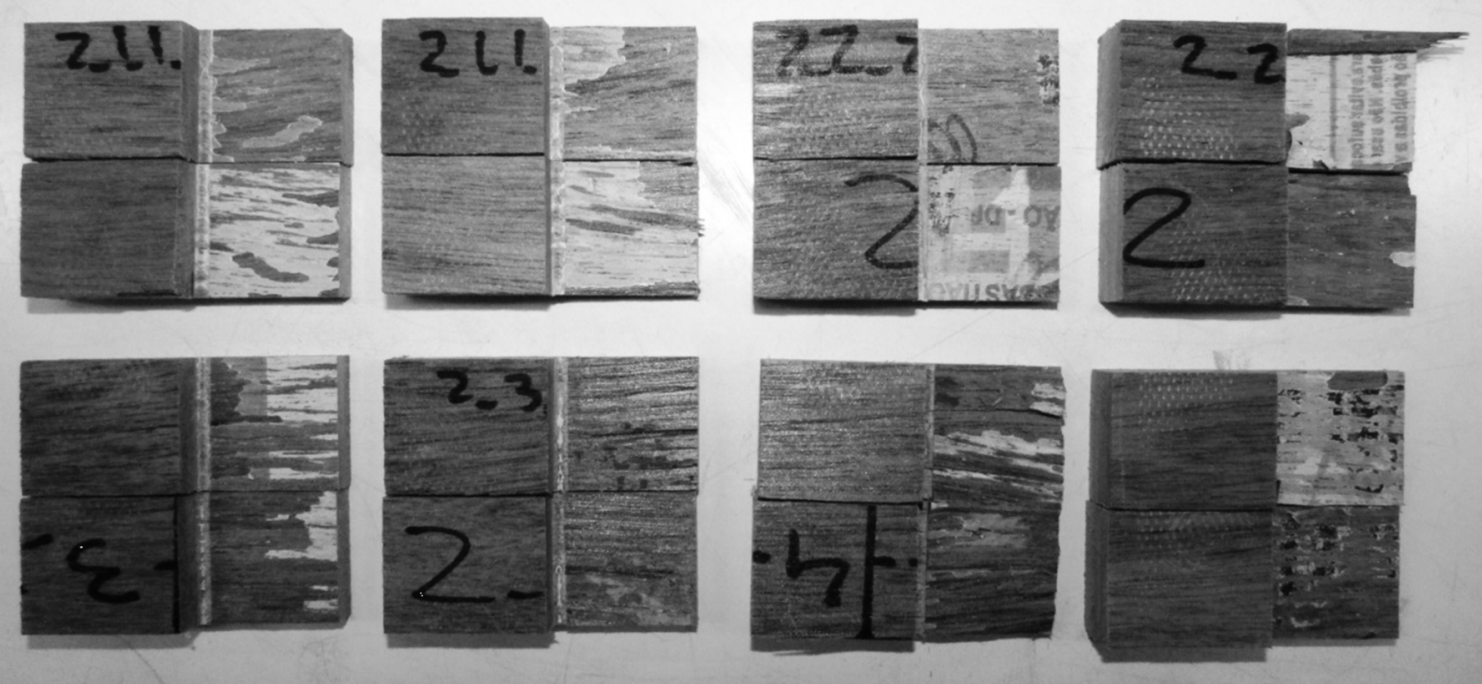

Figure 2. Pattern of ruptures observed in the parallel shear strength test of the LVL-HDPE composite boards. 
of elasticity by non-destructive methods, for boards with 13 veneers, found mean values of bond strength to shear stress in dry condition ranging from 5.07 to $6.70 \mathrm{~N} / \mathrm{mm}^{2}$. Souza et al. ${ }^{12}$ found parallel shear values to the glue line $\left(f_{\mathrm{v}, 0}\right)$ of $9.8 \mathrm{~N} / \mathrm{mm}^{2}$ and $8.7 \mathrm{~N} / \mathrm{mm}^{2}$ to LVLs boards of $P$. oocarpa and $P$. kesiya. Palma \& Ballarin ${ }^{13}$ in the properties study of LVL boards with $E$. grandis, in the L-X plane, found strength values to the parallel shear ranging from 3.66 to $8.66 \mathrm{~N} / \mathrm{mm}^{2}$, with an average of $5.91 \mathrm{~N} / \mathrm{mm}^{2}$.

In a study on the Eucalyptus LVL found strength mean values of the glue line to shear stresses, dry test, ranging from

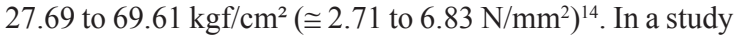
on the production of plywood boards with wood veneers of Sequoia sempervirens and urea-formaldehyde resin, for the strength essay of the glue line to shear stress, in the dry test, obtained values from 1.0 to $1.36 \mathrm{~N} / \mathrm{mm}^{2[16]}$.

The values of the mechanical properties presented by the LVL-HDPE composite board can be considered suitable compared to others found in the literature, as those found in some standards. According to Palma \& Ballarin ${ }^{13}$ characteristic values $\left(f_{k}\right)$ of modulus of rupture for $1.5 \mathrm{E}$ graded LVL should be at least $32.6 \mathrm{~N} / \mathrm{mm}^{2}$, while for $2.1 \mathrm{E}$ it should be $44.9 \mathrm{~N} / \mathrm{mm}^{2}$. The values listed below are not $\mathrm{f}_{\mathrm{k}}$ values but considering it as $70 \%$ of the mean value of the strength properties, the following values are obtained when mean value of the three treatment is considered: $\mathrm{f}_{\mathrm{m}, \mathrm{k}}=65.6 \mathrm{~N} / \mathrm{mm}^{2}$ and $\mathrm{f}_{\mathrm{c}, 0, \mathrm{k}}=37.7 \mathrm{~N} / \mathrm{mm}^{2}$. Kerto ${ }^{17}$ presented LVL characteristic values and it can be observed that the LVL board met the requirement for modulus of rupture $\left(36.0 \mathrm{~N} / \mathrm{mm}^{2}\right.$ vs $\left.65.6 \mathrm{~N} / \mathrm{mm}^{2}\right)$, parallel compression strength $\left(26 \mathrm{~N} / \mathrm{mm}^{2}\right.$ vs $\left.37.1 \mathrm{~N} / \mathrm{mm}^{2}\right)$, but did not for modulus of elasticity $\left(10500 \mathrm{~N} / \mathrm{mm}^{2} v s 10440 \mathrm{~N} / \mathrm{mm}^{2}\right)$. In this context, it can be inferred that proposed LVL-HDPE composite board presented mechanical properties that able it to be used in the same end use of the LVL manufactured using thermosetting resins.

\subsection{Dimensional stability}

The mean values observed for thickness swelling (\%) ranged from $2.82 \%$ to $3.25 \%$ for $2 \mathrm{~h}$ and from $5.50 \%$ to $6.18 \%$ for $24 \mathrm{~h}$. The $350 \mathrm{~g} / \mathrm{m}^{2}$ treatment showed lower thickness swelling percentage for two periods ( $2 \mathrm{~h}$ and $24 \mathrm{~h}$ ), but the $250 \mathrm{~g} / \mathrm{m}^{2}$ treatment showed a higher thickness swelling percentage for two periods ( $2 \mathrm{~h}$ and $24 \mathrm{~h}$ ). However, there was no statistical difference, according to Figure 3.
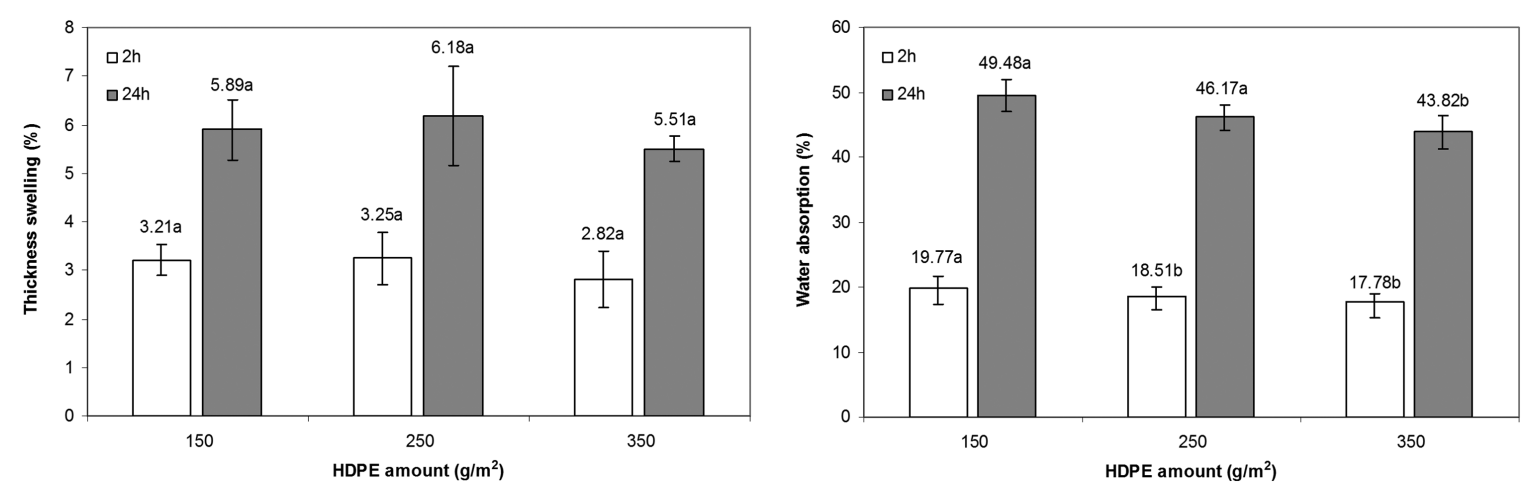

Figure 3. Effect of HDPE amount on the dimensional stability properties of the LVL-HDPE composite board after 2 and 24 of water immersion. (Vertical bar: standard deviation; means followed by different letter denotes that they are statistically different according to the Tukey test at $\alpha=0.05$ ).

When considering the moisture effect in wood boards, the most important factor may be the thickness swelling, which may be affected by diverse variables such as species, board density, glue spread rate, adhesive distribution, and pressing conditions. Pio ${ }^{11}$ found mean values of thickness swelling for boards of 15 years, ranging from $5.52 \%$ to $7.11 \%$ for $2 \mathrm{~h}$ and for boards of 20 years, he found values ranging from $6.55 \%$ to $9.98 \%$, while for $24 \mathrm{~h}$, boards of 15 years showed values ranging from $9.06 \%$ to $10.10 \%$ and for 20 years, values ranging from $8.27 \%$ to $10.69 \%$.

In a study on the influence of different combinations of E. saligna and P. taeda veneers in LVL structural boards, using adhesive based on phenol formaldehyde, found mean values for thickness swelling for $2 \mathrm{~h}$ ranging from $4.17 \%$ to $5.97 \%$ and for the $24 \mathrm{~h}$ ranging from $6.45 \%$ to $9.04 \%{ }^{18}$.

The mean values observed for water absorption (\%) ranged from $17.78 \%$ to $19.77 \%$ for $2 \mathrm{~h}$ and from $43.82 \%$ to $49.48 \%$ for $24 \mathrm{~h}$. The $350 \mathrm{~g} / \mathrm{m}^{2}$ treatment showed lower water absorption for the two periods ( $2 \mathrm{~h}$ and $24 \mathrm{~h}$ ), but the $150 \mathrm{~g} / \mathrm{m}^{2}$ treatment showed a higher percentage of water absorption for the two periods ( $2 \mathrm{~h}$ and $24 \mathrm{~h}$ ), which is consistent with $\mathrm{Pio}^{11}$, the lower the density, the higher the water absorption. There was a significant difference, as shown in Figure 3. Since the plastic is hydrophobic material, eventually act as a barrier to water penetration in the composite, then a larger amount of plastic leads to lower water absorption in the composite.

$\mathrm{Pio}^{11}$ found mean values of water absorption for boards of 15 years ranging from $4.83 \%$ to $5.84 \%$ for $2 \mathrm{~h}$ and for 20 years values ranging from $3.24 \%$ to $4.15 \%$, while for $24 \mathrm{~h}$ the boards of 15 years showed values ranging from $14.09 \%$ to $18.14 \%$ and for 20 years values ranging from $10.35 \%$ to $11.98 \%$. Müller ${ }^{18}$ found water absorption values ranging from $5.07 \%$ to $22.68 \%$ for $2 \mathrm{hs}$ and values ranging from $22.19 \%$ to $42.55 \%$ for $24 \mathrm{hs}$.

\subsection{Estimated properties in the same density level}

Table 2 shows the Pearson correlations and demonstrates that the density affects some physical and mechanical properties of the LVL-HDPE composite board, which are: modulus of rupture $\left(f_{\mathrm{m}}\right)$, modulus of elasticity $\left(E_{M}\right)$, hardness $\left(f_{\mathrm{H}}\right)$, shear $\left(f_{\mathrm{v}, 0}\right)$ and water absorption. It can be observed that the higher the density, the higher the mechanical properties. On the other hand, the increasing of the density reduces the 
Table 2. Pearson correlation between density and properties of the LVL-HDPE composite board.

\begin{tabular}{clcc}
\hline Property & Density & Property & Density \\
\hline $\mathrm{f}_{\mathrm{c}, 0}$ & $0.355^{\mathrm{NS}}$ & $\mathrm{f}_{\mathrm{H}}$ & $0.604^{* *}$ \\
$\mathrm{f}_{\mathrm{v}, 0}$ & $0.543^{* *}$ & $\mathrm{WA} 2 \mathrm{~h}$ & $-0.590^{* *}$ \\
$\mathrm{f}_{\mathrm{M}}$ & $0.458^{*}$ & $\mathrm{WA} 24 \mathrm{~h}$ & $-0.721^{* *}$ \\
$\mathrm{E}_{\mathrm{M}}$ & $0.718^{* *}$ & $\mathrm{TS} 2 \mathrm{~h}$ & $-0.149^{\mathrm{NS}}$ \\
Screw & $0.218^{\mathrm{NS}}$ & $\mathrm{TS} 24 \mathrm{~h}$ & $0.059^{\mathrm{NS}}$ \\
\hline
\end{tabular}

$* * *$ Correlation is significant at the $\alpha=0.05$ and $\alpha=0.01$, respectively. NS: non statistically significant.

values of the water absorption, which leads to a certain level of dimensional stability improvement. As seen in previous paragraph the density improvement was observed because of the increasing amount of the HDPE on the composite boards.

Therefore, it is necessary to remove the density effect to obtain only the HDPE amount effect on the composite board properties. This way, a factorial statistical analysis adopting the density as a cofactor was run. In this analysis the properties of the LVL-HDPE composite boards were estimated for the material in the same density $\left(\rho=657 \mathrm{~kg} / \mathrm{m}^{3}\right)$ and the values obtained are shown in Table 3 . It can be observed that in the same density level the properties of the LVL-HDPE composite boards presented values statistically equals, except for Janka hardness. In this context, it can be concluded that the utilization of the $350 \mathrm{~g} / \mathrm{m}^{2}$ of HDPE is the better strategy because it allows the consumption of higher amount of the plastic residues contributing to the recycling process.

\section{References}

1. Compromisso Empresarial para a Reciclagem - CEMPRE. Plásticos, fichas técnicas. São Paulo; 2011.

2. Associação Brasileira de Empresas de Limpeza Pública e Resíduos Especiais-ABRELPE. Panorama dos resíduos sólidos no Brasil. São Paulo; 2012.

3. Associação Brasileira da Indústria de Embalagens Plásticas Flexíveis - ABIEF. Polietilenos são as resinas mais usadas em embalagens flexíveis. São Paulo; 2014.

4. Milagres EG, Vital BR, Lúcia RMD and Pimenta AS. Compósitos de partículas de madeira de Eucalyptus grandis, polipropileno e polietileno de alta e baixa densidades. Revista Árvore. 2006; 30(3):463-470. http://dx.doi.org/10.1590/S0100-67622006000300017.

5. Lima NN. Painéis laminados e particulados à base de madeiras tropicais da Amazônia. [Thesis]. Lavras: Universidade Federal de Lavras; 2001.

6. Renzo R. Painel estrutural de lâminas paralelas (PLP) de Eucalyptus grandis utilizando adesivo resorcinólico, taninos e poliuretano derivado de óleo de mamona. [Dissertation]. Lavras: Universidade Federal de Lavras; 2008.

7. Amorim MRS. Agrupamento de espécies madeireiras amazônicas para a produção de painéis de lâminas paralelas (LVL). [Dissertation]. Brasília: Universidade de Brasília; 2012.

8. American Society For Testing And Materials-ASTM. ASTMD 1037: Standard test methods of evaluating properties of woodbased fiber and particle board materials. Philadelphia; 2006.

9. American Society For Testing And Materials - ASTM. ASTM D 5456: Standard specification for evaluation of structural composite lumber products. Philadelphia; 2006.
Table 3. Estimated values of the properties of the LVL-HDPE composite boards in the same density $\left(\rho=657 \mathrm{~kg} / \mathrm{m}^{3}\right)$.

\begin{tabular}{cccc}
\hline & \multicolumn{3}{c}{ HDPE amount $\left(\mathbf{g} / \mathbf{m}^{2}\right)$} \\
\hline Property & $\mathbf{1 5 0}$ & $\mathbf{2 5 0}$ & $\mathbf{3 5 0}$ \\
\hline $\mathrm{f}_{\mathrm{M}}\left(\mathrm{N} / \mathrm{mm}^{2}\right)$ & $93.9 \mathrm{a}$ & $96.2 \mathrm{a}$ & $91.0 \mathrm{a}$ \\
$\mathrm{E}_{\mathrm{M}}\left(\mathrm{N} / \mathrm{mm}^{2}\right)$ & $10290 \mathrm{a}$ & $10197 \mathrm{a}$ & $10831 \mathrm{a}$ \\
$\mathrm{f}_{\mathrm{v}, 0}\left(\mathrm{~N} / \mathrm{mm}^{2}\right)$ & $2.22 \mathrm{a}$ & $2.39 \mathrm{a}$ & $2.32 \mathrm{a}$ \\
$\mathrm{f}_{\mathrm{H}}(\mathrm{N})$ & $3158 \mathrm{a}$ & $4380 \mathrm{ab}$ & $4512 \mathrm{~b}$ \\
$\mathrm{WA} 2 \mathrm{~h}(\%)$ & $18.7 \mathrm{a}$ & $19.1 \mathrm{a}$ & $18.3 \mathrm{a}$ \\
$\mathrm{WA24h}(\%)$ & $47.8 \mathrm{a}$ & $47.1 \mathrm{a}$ & $44.7 \mathrm{a}$ \\
\hline
\end{tabular}

At same line means followed by different letter denotes that they are statistically different according to the Bonferroni test at $\alpha=0.05$.

\section{Conclusions}

The production of the proposed laminated veneer lumber (LVL) utilizing high-density polyethylene (HDPE) from supermarket plastic bags as binder is technically possible. In general, LVL-HDPE composite boards showed good quality without any occurrence of neither delamination nor bubbles. It was found that the utilization of increasing amount of HDPE led to density improvement, which affected positively mechanical and physical properties of the LVL-HDPE composite board. Mechanical properties were similar or higher than those found in LVL manufactured using thermosetting resin and they met international standards. The composite boards made with the $350 \mathrm{~g} / \mathrm{m}^{2} \mathrm{HDPE}$ amount showed better mechanical and dimensional stability properties.

10. European Standard-EN. EM 314-1: BS Plywood-Bond Quality - Test methods. Brussels; 2004.

11. Pio NS. Produção de painéis estruturais de lâminas paralelas (PLP) de Eucalyptus grandis Hill ex-Maiden. [Thesis]. Curitiba: Universidade Federal do Paraná; 2002.

12. Souza F, Del Menezzi CHS and Bortoletto G Jr. Material properties and nondestructive evaluation of laminated veneer lumber (LVL) made from Pinus oocarpa and P. kesiya. European Journal of Wood and Wood Products. 2011; 69(2):183-192. http://dx.doi. org/10.1007/s00107-010-0415-0.

13. Palma HAL and Ballarin AW. Propriedades físicas e mecânicas de painéis LVL de Eucalyptus grandis. Ciência Florestal. 2011; 21:559-566.

14. Iwakiri S, Matos JLM, Prata JG, Torquato LP, Bronoski M, Nishidate MM. Produção de painéis laminados unidirecional - LVL com madeiras de Eucalyptus grandis Hill ex Maiden E Eucalyptus dunnii Maiden. Floresta e Ambiente. 2008; 15:1-7.

15. Gabriel MSC. Desempenho físico-mecânico de painéis LVL de Pinus tropicais da região de São Paulo. [Thesis]. Botucatu: Universidade Estadual Paulista; 2007.

16. Iwakiri S, Cunha AB, Prata JG, Braz RL, Castro VG, Kazmierczak $\mathrm{S}$, et al. Produção de painéis compensados com lâminas de madeira de Sequoia sempervirens e resina ureia-formaldeído. Floresta. 2012; 42(4):809-816. http://dx.doi.org/10.5380/rf.v42i4.25688.

17. KERTO. All benefits of timber. All strengths of composites. 2012. Available from: $<$ http://www.ffebrochure.eu/Finland/finnforest/ Kerto_eng/files/kerto_eng.pdf $>$. Access in: 6/9/2012.

18. Müller MT. Influência de diferentes combinações de lâminas de Eucalyptus saligna e Pinus taeda em painéis estruturais $L V L$. [Dissertation]. Santa Maria: Universidade Federal de Santa Maria; 2009. 